\title{
Osmanlı Kentlerinde 19. Yüzyıldaki Do̊nůşůmler: Prof. Dr. Nur Akın İçin Makaleler
}

\section{Ceylan İrem Gençer* Yıldız Salman**}

Türkiye'de tarihi çevre koruma alanındaki önemli ilk isimlerden Prof. Dr. Nur Akın, verdiği derslerde öğrencilerine özellikle kentsel dokuyla sosyal yapıyı bir bütün olarak incelemeyi aşılamıştır. Kendisinin İstanbul Teknik Üniversitesi (İTÜ), Fen Bilimleri Enstitüsü Restorasyon Doktora Programı'ndaki “19. Yüzyıl İstanbul'unda Kentsel ve Mimari Dönüşüm” dersi, restorasyon programı dışından da yoğun katılımın olduğu derslerden biri olageldi. İstanbul'un 19. yüzyıldaki kozmopolit yapısı ile kentin mimari ve kentsel dönüşüm sürecini tüm aktörleriyle ve dönemin sosyo-politik dinamikleriyle ele alması, bu dersi alan bizlerin kente yönelik bütüncül bir bakış elde etmemizde ve kentlerin tarihsel değişim süreçlerine ilgi duymamızdaki temel itici güç olmuştur. Bu ders, bilgi birikimini paylaşırken bizlere geçen yüksek enerjisi ve heyecanı ile tartışmasız en etkileyici, en unutulmaz derslerimizden birisiydi.

Bizler de bugün hocamızın bize kattıklarıyla bu dersi benzer bir biçimde kendi programlarımızda devam ettiriyoruz. İTÜ ve Yıldız Teknik Üniversitesi (YTÜ) Restorasyon Doktora programlarındaki derslerimizin sonuç ürünlerinden oluşan bir seçkiyi, Meltem İmir Akdeniz Akademisi Dergisi'nde bir dizi makale olarak kendisine armağan etmek istiyoruz.

Bu seçkinin Meltem'in bu sayısında yer alan ilk iki makalesi de İstanbul'un 19. yüzyılda önemli değişimler geçiren iki semtine odaklanıyor. Bu makaleler, YTÜ Rölöve Restorasyon Doktora Programı kapsamında, Doç. Dr. Ceylan İrem Gençer tarafından yürütülen 19. Yüzyıl Osmanlı Kentlerinde Dönüşüm dersinde hazırlanan raporların genişletilmiş halidir. Melis Bilgiç'in "Osmanlı Kentlerinde 19. Yüzyıldaki Dönüşümler: İstanbul, Fener Örneği" ve Selin Akdeğirmen Ercan'ın “Osmanlı Kentlerinde 19. Yüzyıldaki Dönüşümler: İstanbul, Büyükdere Örneği" makaleleri, arşiv belgelerinden elde edilen bilgiler ışığında bu semtlerdeki dönüşümlerin farklı yönlerini ele alıyor.

Sevgili Nur Akın’a sonsuz teşekkürlerimizle.

* Yıldız Teknik Üniversitesi, Mimarlık Bölümü

** İstanbul Teknik Üniversitesi, Mimarlık Bölümü 